Pesq. Vet. Bras. 35(6):573-578, junho 2015 DOI: $10.1590 / \mathrm{S} 0100-736 \mathrm{X} 2015000600015$

\title{
Serological monitoring of antibodies for an early diagnosis of aspergillosis in captive penguins ${ }^{1}$
}

\author{
Ângela L. Cabana ${ }^{2 *}$, Melissa O. Xavier³, Vanice Poester ${ }^{3}$, Gabriel B. Klafke ${ }^{3}$, Pedro \\ L.B. Filho ${ }^{4}$, Aryse Martins ${ }^{4}$, Rodolfo P.S. Filho ${ }^{4}$ and Mário C.A. Meireles ${ }^{2}$
}

\begin{abstract}
Cabana A.L., Xavier M.O., Poester V., Klafke G.B., Bruno-Filho P.L., Martins A., Silva-Filho R.P. \& Meireles M.C.A. 2015. Serological monitoring of antibodies for an early diagnosis of aspergillosis in captive penguins. Pesquisa Veterinária Brasileira 35(6):573-578. Laboratório de Micologia, Setor de Doenças Infecciosas, Faculdade de Veterinária, Universidade Federal de Pelotas, Campus Universitário s/n, Pelotas, RS 96010900, Brazil. E-mail: cabanangela@gmail.com

This study aimed to evaluate the efficacy of detection of anti-Aspergillus fumigatus antibodies in captive penguins by double radial agar gel immunodiffusion (AGID) for the aspergillosis diagnosis. We included 134 Magellanic penguins (Spheniscus magellanicus) in rehabilitation at the Center for Recovery of Marine Animals (CRAM / FURG). All of them were monitored by AGID weekly until its final destination (death or release), totalizing 660 serum samples studied. All animals were clinically accompanied and post-mortem examinations was performed in penguins that died during the studied period. A total of $28 \%$ (37/134) of the penguins died, 89.2\% (33/37) due to aspergillosis, 11\% (4/37) by other causes and 97 were released. From the 33 animals with proven aspergillosis, 21 presented anti- A. fumigatus antibodies by AGID, being the average interval between death and positive AGID 16.4 days. Twelve animals with negative serology died of aspergillosis. The sensitivity and specificity rates were $63.6 \%$ and $95 \%$ respectively, and the positive and negative predictive values were $80.7 \%$ and $88.9 \%$ respectively. These data demonstrate that the serological monitoring for detection of antibodies by AGID can be an important tool for the diagnosis of aspergillosis in penguins.
\end{abstract}

INDEX TERMS: Spheniscus magellanicus, Sphenisciformes, captivity, Aspergillus spp., aspergillosis, antibody, immunodiffusion.

\begin{abstract}
RESUMO.- [Monitoramento sorológico com detecção de anticorpos para diagnóstico precoce da aspergilose em pinguins em cativeiro.] Este estudo teve como objetivo avaliar a eficácia da detecção de anticorpos anti- Aspergillus fumigatus em pinguins em cativeiro por imunodifusão radial dupla em gel de ágar (IDGA) para diagnóstico
\end{abstract}

\footnotetext{
${ }^{1}$ Received on February 20, 2014.

Accepted for publication on July 1, 2015.

${ }^{2}$ Laboratório de Micologia, Faculdade de Veterinária, Campus Universitário Universidade Federal de Pelotas (UFPel) s/n, Capão do Leão, RS 96160000, Brazil. E-mails: meireles@ufpel.edu.br; *Corresponding author: cabanangela@gmail.com

${ }^{3}$ Laboratório de Micologia, Faculdade de Medicina, Campus Saúde Universidade Federal de Rio Grande (FURG); Rua Visconde de Paranaguá 102, Centro, Rio Grande, RS 96203-900, Brazil. E-mails: melissaxavier@ig.com. br, vanicerp@gmail.com, gabrielklafke@yahoo.com.br

${ }^{4}$ Centro de Recuperação de Animais Marinhos (CRAM), FURG, Rua Capitão Heitor Perdigão 10, Rio Grande, RS 96200580. E-mails: pedro_lbf@ hotmail.com, arysemartins@gmail.com, musbird@furg.br
}

da aspergilose. Foram incluídos 134 pingüins de Magalhães (Spheniscus magellanicus) em reabilitação no Centro de Recuperação de Animais Marinhos (CRAM/FURG), que foram monitoradas por IDGA, semanalmente, até o seu destino final (morte ou de liberação), totalizando 660 amostras de soro estudadas. Todos os animais foram acompanhados clinicamente e exames post mortem foram realizados em pingüins que vieram a óbito durante o período de estudo. Um total de 28\% (37/134) dos pinguins foram a óbito, 89,2\% (33/37) de aspergilose, 11\% (4/37) de outras causas, e 97 foram liberados. A partir dos 33 animais com aspergilose comprovada, 21 apresentaram anticorpos anti- $A$. fumigatus por IDGA, sendo o intervalo médio entre a morte e IDGA positivas 16,4 dias. Doze animais com sorologia negativa vieram a óbito por aspergilose. As taxas de sensibilidade e especificidade foram de $63,6 \%$ e $95 \%$, respectivamente, e os valores preditivos positivos e negativos foram de $80,7 \%$ e $88,9 \%$, respectivamente. Estes dados demonstram que 
o monitoramento sorológico para detecção de anticorpos por IDGA pode ser uma ferramenta importante no diagnóstico de aspergilose em pinguins.

TERMOS DE INDEXAÇÃO: Spheniscus magellanicus, Sphenisciformes, cativeiro, Aspergillus sp., aspergilose, anticorpos, imunodifusão.

\section{INTRODUCTION}

Aspergillosis is an infectious, non-contagious disease caused by fungi of the genus Aspergillus, especially those belonging to the section Fumigati (Ainsworth \& Rewell 1949, Abarca 2000, Jones \& Orosz 2000, Carrasco et al. 2001, Arné et al. 2011, Xavier et al. 2011). Although it has a low prevalence in free-living penguins (Hocken 2000, Garcia-Borboroglu et al. 2006), this mycosis is extremely important at captivity sites (zoos, aquariums and rehabilitation centers), where it is considered a major cause of mortality of these seabirds and other species(Khan et al. 1977, Flach et al. 1990, Diebold et al. 1999, Xavier et al. 2007).

Aspergillosis in penguins may result in sudden death, or present unspecific clinical signs such as lethargy and anorexia which may evolve to dyspnea and cyanosis (Khan et al. 1977, Flach et al. 1990, Xavier et al. 2007, Xavieret al. 2011). Alterations in radiological exams such as thickening and opacity of air sacs may be evidenced only in late frames of the disease, and the alterations as heterophilia and eosinophilia on hemogram are unspecific, which does not allow a definitive diagnosis of this mycosis (Jones \& Orosz 2000, Ivey 2000, Beernaert et al. 2010, Cray2011). In addition, classical methods in mycology, as direct examination and cultive have a limited value due to the low sensitivity and specificity, and, in addition, the respiratory tract endoscopy is an invasive method and requires the animal anesthesia. Regarding it, there is no test considered the gold standard for definitive diagnosis of aspergillosis in birds, being the confirmation of the disease often performed only by post-mortem examinations (Redig 1994, Graczyk \& Cockrem 1995, Cray \& Zielezienski-Roberts 1997, Jones \& Orosz 2000, Beernaert et al. 2010, Cray 2011). This data gives to aspergillosis a crucial role as a limitation to penguin rehabilitation or in the ongoing maintenance of these animals in places like zoos and aquariums, causing immeasurable ecological and economic losses (Khan et al. 1977, Flach et al. 1990, Graczyk et al. 1998, Diebold et al. 1999, Carrasco et al. 2001, Sanchez et al. 2005, Xavier et al. 2007).

Most cases of aspergillosis in captive penguins occurs sporadically and is characterized by chronic conditions and advanced disseminated disease that can even present the formation of large granulomatous masses (Ainsworth \& Rewell1949, Khan et al. 1977, Flach et al. 1990, Carcciuttolo et al. 2009, Xavier et al. 2011). Considering that the formation of these aspergillomas is a lengthy process, during which the humoral response can be generated (Martinez-Quesada et al. 1993, Graczyk et al. 1998, Beernaert et al. 2010 ), and that the in vivo diagnosis of aspergillosis is needed to start the specific therapy and achieve clinical cure, this study aimed to evaluate the performance of serological monitoring for detection of anti-Aspergillus fumigatus anti- bodies by double radial agar gel immunodiffusion (AGID) as a method for an early diagnosis of aspergillosis in captive penguins.

\section{MATERIALS AND METHODS}

The study was performed including the Magellanic penguins (Spheniscus magellanicus) in transitory captivity for rehabilitation during the period from June 2009 to December 2011 at the Center for Recovery of Marine Animals of Rio Grande, RS, Brazil(CRAM-FURG, $32^{\circ} 03^{\prime} \mathrm{S}, 52^{\circ} 08^{\prime} \mathrm{W}$ ). The project followed the standards of animal welfare and was approved by the ethics committee of UFPel (n 6919).

All animals were subjected to sampling of peripheral blood by venipuncture from the jugular vein on arrival at the CRAM, and every 7-15 days from the medial metatarsal vein over the entire period of captivity until their destination (release to natural habitat or death). The sera were separated by centrifugation, aliquoted into microtubes and stored at $4^{\circ} \mathrm{C}$ for analysis. Length of stay less than 30 days in CRAM, and animals with only one serum sample collected were excluded from the study.

The serological monitoring was performed weekly for detection of anti-Aspergillus fumigatus antibodies from the AGID technique, as described by Ouchterlonyet al. (1949), utilizing antigen and positive control sera commercially available (Aspergillus fumigatus ID antigen IMMY® e Aspergillus fumigatus ID control IMMY®). Samples were considered positive in the visualization of the identity line (antibody-antigen precipitation line of the sample adjacent to the control line).

The animals were clinically followed up during the period of captivity and all that died underwent post-mortem examinations for the determination of the causa mortis, with evaluation of macroscopic and histopathological alterations, mycological examination with $20 \% \mathrm{KOH}$ and culture of tissue fragments from the respiratory tract (lungs and air sacs) in Sabouraud dextrose agar with chloramphenicol at $37^{\circ} \mathrm{C}$ for up to seven days.

In order to evaluate the test diagnostic precocity, the time between the first positive AGID and death of animals with aspergillosis was calculated. Data were collected for assessment of mortality attributed to aspergillosis in this population, and rates of sensitivity (S), specificity (Sp), positive predictive value (PPV) and negative predictive value (NPV) of AGID in the diagnosis of aspergillosis in penguins were calculated, considering as the gold standard the post-mortem examinations.

\section{RESULTS}

From the 239 Magellanic penguins received in CRAM during the study period, 105 were excluded , 64 by staying less than 30 days in CRAM and 41 by having only one serum sample collected, thus, 134 animals took part on the study. Of these, 33 eventually died of aspergillosis [31 (93.9\%) by Aspergillus section Fumigati and two (6.1\%) by Aspergillus section Flavi], four from other causes, and 97 animals were rehabilitated and released to their habitat. The mortality rate related to aspergillosis in our study was $89.2 \%$.

All 33 cases of aspergillosis included were classified as confirmed cases, with demonstration of granulomatous lesions in the lungs (Fig. 1a), fungal aerosaculitis (Fig.1b), bronchopneumonia and / or necrosis of the tissues involved, associated with the isolation of fungi of the genus Aspergillus in mycological cultive and visualization of hyaline, septate, forked at an acute angle $\left(45^{\circ}\right)$ hyphae and/or typical fruiting structures of the genus Aspergillus in histopathology. 


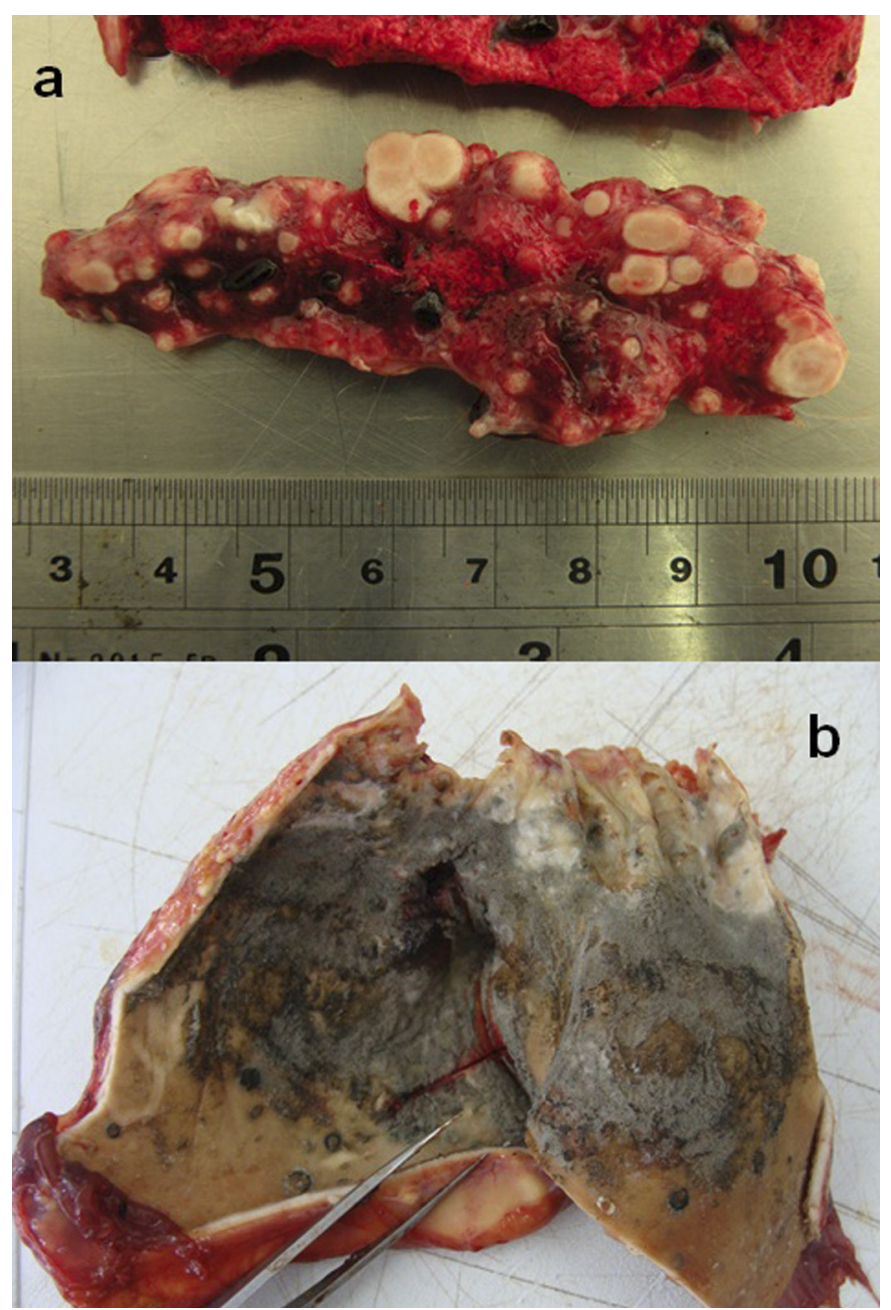

Fig.1. Lesions observed at necropsy of penguins with aspergillosis. (a) Granulomatous lesions in pulmonary parenchyma, white in color and dry in texture. (b) Aerosaculitis showing thickening air sacs with a grey-greenish mould on internal surface typical of fungal sporulation.

An average of four serological tests was performed per animal, ranging from two to ten, according to the period in which the animals were kept in captivity (average of 66 days, ranging from 30 to 271 days). Only about $10 \%$ of the animals $(14 / 134)$ were subjected to only two tests, being the monitoring of the other 120 animals realized by at least three serologic tests, totalizing 660 serum samples tested.

No penguin presented positive AGID on arrival at CRAM. During serological monitoring the presence of anti- $A$. $f u$ migatus antibodies were detected by AGID in 26 animals, from which 21 died of aspergillosis and the other five were released, not showing clinical signs after an average period of 79 days (ranging from 28 to 183 days) from the serology positive result. From the 108 animals that had no positive sample at AGID, twelve died of aspergillosis. This data resulted in rates of $63.6 \%$ of sensitivity, $95 \%$ of specificity, $80.7 \%$ of PPV and $88.9 \%$ of NPV.

From the 33 animals with aspergillosis, eight (24.2\%) had sudden death, without clinical signs. In the remaining 25 animals that died of aspergillosis, the main clinical signs were dyspnea $(n=13,52 \%)$, lethargy $(n=11,44 \%)$, ina- ppetence/anorexia $(n=3,12 \%)$ and/or regurgitation $(n=2$, $8 \%$ ).Considering only the 21 animals with positive serology and who died of aspergillosis, five (23.8\%) had sudden death, with no apparent clinical signs, and six (28.5\%) showed dyspnea before the first positive result of AGID. The mean period between seropositivity and death of the animals was 16.4 days (range 0-59 days) (Table 1 ).

\section{DISCUSSION}

Diagnostic testing in avian species remains in the early stages of development without validation or standardization, which is the major complication in the diagnosis of avian disease (Cray 2011). When dealing specifically with the diagnosis of aspergillosis in penguins, this problem becomes even greater, with few studies published in the literature (Graczyk \& Cockrem 1995, Graczyk et al. 1998, German et al. 2002, Cray et al. 2009a, Cray et al. 2009b, Burco et al. 2012). Therefore the present study evaluated the efficacy of the double radial agar gel immunodiffusion test as a method for diagnosis of aspergillosis in captive penguins from serological monitoring, demonstrating high specificity rates and positive and negative predictive values.

Although the AGID is a quite old technique, it has characteristics that justify its practical applicability to the present day, such as easy operation, especially in the handling of small number of samples, low cost and a minimum requirement for laboratory equipment and structure (Lane \& Warnock 1977, Poli et al. 1981, Billen et al. 2009). In addition, being based on a precipitation reaction, the AGID does not require the use of species-specific secondary antibodies, which are required for indirect ELISA and are not commercially available when dealing with wild animals (Graczyk \& Cockrem 1995, German et al. 2002, Cray et al. 2009a, 2009b, Cray 2011), which is the case in our study with penguins.

Further, unlike what is described in the studies using the ELISA technique to detect antibodies in which a positive result do not necessarily correlate with clinical disease (Graczyk \& Cockrem 1995, German et al. 2002, Cray et al. 2009a, 2009b, Cray 2011), our study with AGID demonstrated high PPV. This discrepancy in the interpretation of a positive result between these two diagnostic techniques is due to that the AGID is less sensitive (Cray 2011), showing positive results only in serum samples with large concentration of circulating antibodies, a condition found only in individuals with active disease. On the other hand, ELISA technique allows disclosure including low concentration of circulating antibodies from just the exposure / infection of the host to the fungus (Graczyk \& Cockrem 1995, Cray et al. 2009a, 2009b).

Most studies related to techniques for early diagnosis of aspergillosis in birds has worked with direct diagnosis methods, newer and more advanced, such as galactomannan detection by sandwich ELISA (Arca-Ruibal et al. 2006, Cray et al. 2009a, 2009b) or even detection of $\beta$-glucan antigen (Burco et al. 2012), not being described in the literature studies similar to ours, showing rates of S, Sp, PPV and NPV for the indirect diagnosis by AGID of aspergillosis in birds. 
Table 1. Clinical-epidemiological and serological data of penguins with aspergillosis

\begin{tabular}{|c|c|c|c|c|c|c|c|}
\hline Penguin & Gender & Age & $\begin{array}{c}\text { Etiology } \\
\text { (Aspergillus } \\
\text { section) }\end{array}$ & $\begin{array}{l}\text { Clinical } \\
\text { signs }\end{array}$ & Serology & $\begin{array}{l}\text { Number of } \\
\text { serological } \\
\text { tests }\end{array}$ & $\begin{array}{l}\text { Period between } \\
\text { positive serology } \\
\text { and death (days) }\end{array}$ \\
\hline 1 & $\mathrm{U}$ & J & Fumigati & Lethargy & NEG & 4 & - \\
\hline 2 & $\mathrm{U}$ & J & Fumigati & Lethargy & NEG & 3 & - \\
\hline 3 & $\mathrm{~F}$ & J & Fumigati & WCS & NEG & 3 & - \\
\hline 4 & M & $\mathrm{J}$ & Fumigati & WCS & NEG & 4 & - \\
\hline 5 & $\mathrm{~F}$ & $\mathrm{~J}$ & Fumigati & $\begin{array}{c}\text { Anorexia, repeated } \\
\text { vomiting }\end{array}$ & $\mathrm{NEG}$ & 6 & - \\
\hline 6 & $\mathrm{~F}$ & $\mathrm{~J}$ & Fumigati & Dyspnea & NEG & 4 & - \\
\hline 7 & M & $\mathrm{J}$ & Fumigati & Lethargy & NEG & 4 & - \\
\hline 8 & M & $\mathrm{J}$ & Fumigati & Anorexia & NEG & 3 & - \\
\hline 9 & $\mathrm{~F}$ & J & Fumigati & WCS & NEG & 2 & - \\
\hline 10 & M & J & Fumigati & Dyspnea & NEG & 3 & - \\
\hline 11 & $\mathrm{U}$ & $\mathrm{J}$ & Fumigati & Dyspnea & NEG & 3 & - \\
\hline 12 & $\mathrm{~F}$ & J & Fumigati & Dyspnea & NEG & 4 & - \\
\hline 13 & $\mathrm{U}$ & I & Fumigati & Dyspnea & POS & 3 & 08 \\
\hline 14 & $\mathrm{U}$ & I & Flavi & Lethargy & POS & 5 & 00 \\
\hline 15 & $\mathrm{~F}$ & $\mathrm{~J}$ & Fumigati & WCS & POS & 4 & 00 \\
\hline 16 & M & J & Fumigati & Dyspnea & POS & 4 & 21 \\
\hline 17 & $\mathrm{U}$ & J & Fumigati & Lethargy & POS & 6 & 24 \\
\hline 18 & M & J & Fumigati & Dyspnea & POS & 2 & 18 \\
\hline 19 & $\mathrm{U}$ & J & Fumigati & Lethargy & POS & 5 & 02 \\
\hline 20 & $\mathrm{~F}$ & $\mathrm{~J}$ & Fumigati & $\begin{array}{c}\text { Dyspnea, repeated } \\
\text { vomiting }\end{array}$ & POS & 5 & 03 \\
\hline 21 & $\mathrm{~F}$ & $\mathrm{~J}$ & Fumigati & $\begin{array}{c}\text { Lethargy, Anorexia, } \\
\text { Dyspnea }\end{array}$ & POS & 7 & 21 \\
\hline 22 & $\mathrm{U}$ & I & Fumigati & Lethargy & POS & 3 & 24 \\
\hline 23 & $\mathrm{U}$ & I & Fumigati & Lethargy & POS & 7 & 59 \\
\hline 24 & $\mathrm{U}$ & A & Fumigati & Dyspnea, keratitis & POS & 10 & 02 \\
\hline 25 & $\mathrm{~F}$ & $\mathrm{~J}$ & Fumigati & Dyspnea & POS & 4 & 28 \\
\hline 26 & M & $\mathrm{J}$ & Fumigati & Dyspnea & POS & 9 & 31 \\
\hline 27 & $\mathrm{U}$ & $\mathrm{J}$ & Fumigati & Lethargy & POS & 4 & 33 \\
\hline 28 & M & $\mathrm{J}$ & Flavi & WCS & POS & 2 & 13 \\
\hline 29 & $\mathrm{U}$ & J & Fumigati & Lethargy & POS & 3 & 42 \\
\hline 30 & $\mathrm{U}$ & I & Fumigati & WCS & POS & 5 & 05 \\
\hline 31 & $\mathrm{U}$ & I & Fumigati & WCS & POS & 6 & 05 \\
\hline 32 & $\mathrm{~F}$ & J & Fumigati & WCS & POS & 2 & 06 \\
\hline 33 & $\mathrm{U}$ & A & Fumigati & Dyspnea & POS & 4 & 00 \\
\hline
\end{tabular}

Although these direct diagnostic techniques seeking fungal antigen detection demonstrate promising results, it should be noted that these tests are not yet standardized for other types of hosts than humans, with no defined cutoff, and still has poor accessibility, high cost and large variability in results depending on the population studied (Wheat 2003, Arca-Ruibal et al. 2006, Aquino et al. 2007, Cray et al. 2009a, 2009b, Burco et al. 2012).

In addition, the rates of S, Sp, PPV and NPV for the AGID diagnosis of aspergillosis in penguins found in our study are similar or even superior to those described by Arca-Ruibal et al.(2006), in their study with galactomannan detection for the diagnosis of aspergillosis in falcons $(12 \%$ S, 95\% Sp, 46.1\% PPV and 75.4\% of VPN using cut-off $=1.0$ ), and by Cray et al. (2009a, 2009b) who found 67\% sensitivity, $73 \%$ specificity, $63 \%$ PPV and 76\% NPV using the same technique (cut-off $=0.5$ ) for the diagnosis of aspergillosis in bird from different species. Likewise, the results are superior to those described by Burco et al. (2012), who used the technique to detect $\beta$-glucan for diagnosis of aspergillosis in birds finding rates of sensitivity and specificity of $60 \%$ and $92.7 \%$, respectively.
The high rates of specificity, PPV and NPV found in our study, all above $80 \%$, suggests the applicability of the test as a diagnostic method of aspergillosis in penguins, corroborating with other authors who claim that penguins respond to infection by Aspergillus spp. with large amounts of antibodies production (Cray 2011), probably due to the chronicity of the lesions that occurs with slow progression (Ainsworth \& Rewell 1949, Carrasco et al. 2001, Xavier et al. 2011). These data justify the better results of indirect serologic tests compared with direct diagnostic methods previously studied and described above.

The false negative results in AGID found in twelve penguins who died of aspergillosis in our study may be due to factors of immunosuppression, either by stress, individual weakness (we should also consider that the animals were in different stages of rehabilitation) or even by the individual susceptibility to gliotoxin, toxin with deleterious action on the immune system produced in vivo by the etiologic agent, which culminates with low production of antibodies by the host (Ouchterlony et al. 1949, Graczyk et al. 1998, Nieminen et al. 2002, Cray et al. 2009a, 2009b, Beernaert et al. 2010, Arné et al. 2011). Another possibility would 
be the acute death of these animals prior to sufficient production of IgG required to be detected by AGID (Graczyk et al. 1998). In these cases of immunosuppression, these individuals could be benefited from a direct diagnostic test, such as sandwich ELISA for detection of galactomannan whose results do not require host immune integrity, being their positivity directly related to the low concentration of circulating antibodies (Aquino et al. 2007, Cray 2011).

On the other hand, the soropositivity found in five animals that were released to their natural habitat could be attributed to a spontaneous regression of the infection. Probably those penguins were infected and were able to suppress the fungus with their own immune response. In fact, since we did not had access to another confirmatory test for the diagnostic of aspergillosis in vivo, all cases were confirmed only at necropsy of those animals that died. Thus we can not affirm that these were false-positive results.

Considering that only six penguins showed clinical signs before the first positive serology and that the average time between the first positive AGID and death from aspergillosis was about fifteen days, associated with high rates of the predictive values described in our study, we suggest that the result of this serological monitoring may be used as abutment for starting preemptive aspergillosis therapy in penguins at risk of the disease. This would be similar to that recommended for neutropenic human patients at risk of invasive aspergillosis, who must be monitored by antigenemia tests for detection of galactomannan (Maertens et al. 2001, Aquino et al. 2007).

The serological monitoring for detection of specific antibodies by double immunodiffusion is useful for detection of aspergillosis in captive penguins in risk of developing the disease, with high rates of specificity, PPV and NPV. However, more studies are needed on the prognosis in cases of aspergillosis in penguins whose therapeutic intervention is based on the diagnosis by AGID, considering that the average period between the positive result of this test and the death of the animal was less than a month.

Acknowledgements.- This study was supported by Conselho Nacional de Desenvolvimento Científico e Tecnológico (CNPq) grant no 485489/20120 (Edital Universal 14/2012).

\section{REFERENCES}

Abarca M.L. 2000. Taxonomy of species involved and identification in the nosocomial aspergillosis. Revta Iberoam. Micol. 17:79-84.

Ainsworth G.C. \& Rewell R.E. 1949. The incidence of aspergillosis in captive wild birds. J. Comp. Pathol. Therap. 59:213-224.

Aquino V., Goldani L.Z. \& Pasqualoto A.C. 2007. Update on the contribution of galactomannan for the diagnosis of invasive aspergillosis. Mycopathol. 163:191-202.

Arca-Ruibal B., Wernery U., Zachariah R., Bailey T.A., Somma A.D., Silvanose C. \& McKinney P. 2006. Assessment of a commercial sandwich ELISA in the diagnosis of aspergillosis in falcons. Vet. Rec. 158:442-444.

Arné P., Thierry S., Wang D., Deville D., Le Loch G., Desouter A., Féménia F., Huang W., Chermette R. \& Guillot J. 2011. Aspergillus fumigatus in poultry. Int. J. Microbiol. 2011:1-14.

Beernaert L.A., Pasmans F., Van Waeyenberghe L., Haesebrouck F. \& Martel A. 2010. Aspergillus infections in birds: a review. Avian Pathol. 39:325331.
Billen F., Peeters D., Peters I.R., Helps C.R., Huynen O., De Mol P., Massart L., Day M.J. \& Clercx C. 2009. Comparison of the value of measurement of serum galactomannan and Aspergillus-specific antibodies in the diagnosis of canine sino-nasal aspergillosis. Vet. Microbiol. 133:358365.

Burco J.D., Ziccardi M.H., Clemons K.V. \& Tell L.A. 2012. Evaluation of plasma $(1 \rightarrow 3) \beta$-D-glucan concentrations in birds naturally and experimentally infected with Aspergillus fumigatus. Avian Dis. 56:183-191.

Carcciuttolo E., Rossi G., Nardoni S., Legrottaglie R. \& Mani P. 2009. Anatomopathological aspects of avian aspergillosis. Vet. Res. Commun. 33:521-527.

Carrasco L., Lima Jr J.S., Halfen D.C., Salguero F.J., Sánchez-Cordon P. \& Becker G. 2001. Systemic Aspergillosis in an Oiled Magellanic Penguin (Spheniscus magellanicus). J. Vet. Med. 48:551-554.

Cray C., Watson T. \& Arheart K.L. 2009a. Serosurvey and diagnostic application of antibody titers to Aspergillus in avian species. Avian Dis. 53:491-494

Cray C., Watson T., Rodriguez M. \& Arheart K.L. 2009b. Application of galactomannan analysis and protein electrophoresis in the diagnosis of aspergillosis in avian species. J. Zoo Wildl. Med. 40:64-70.

Cray C. \& Zielezienski-Roberts K. 1997. Application of Aspergillus antigen assay in the diagnosis of aspergillosis. Proc. Annual Conference of the Association of Avian Veterinarians, Sept.10-12, Reno, USA, p.219221.

Cray C. 2011.Infectious and zoonotic disease testing in pet birds. Clin. Lab. Med. 31:71-85.

Diebold E.N., Branch S. \& Henry L. 1999. Management of penguin population in North American zoos and aquariums. Mar Ornithol. 27:171-176.

Flach E.J., Stevensom M.F. \& Henderson G.M. 1990. Aspergillosis in Gentoo penguins (Pygoscelis papua) at Edinburgh Zoo, 1964-1988. Vet. Rec. 126:81-85.

Garcia-Borboroglu P., Boersma P.D., Ruoppolo V., Reyes L., Rebstock G.A., Griot K., Heredia S.R., Adornes A.C. \& Silva R.P. 2006. Chronic oil pollution harms Magellanic penguins in the Southwest Atlantic. Mar. Poll. Bull. 52:193-198.

German A.C., Shanklan G.S., Edwards J. \& Flach E.J. 2002. Development of an indirect ELISA for the detection of serum antibodies to Aspergillus fumigatus in captive penguins. Vet. Rec. 150:513-518.

Graczyk T.K. \& Cockrem J.F. 1995. Aspergillus spp seropositivity in New Zealand penguins. Mycopathol. 131:179-184.

Graczyk T.L., Cranfield M.R. \& Klein P.N. 1998.Value of antigen and antibody detection, and blood evaluation parameters in diagnosis of avian invasive Aspergillosis. Mycopathol. 140:121-127.

Hocken A.G. 2000. Cause of death in blue penguins (Eudyptula m. minor) in North Otago, New Zealand. N.Z. J. Zoo 27:305-309.

Ivey E.S. 2000. Serologic and plasma protein electrophoretic findings in 7 psittacine birds with aspergillosis. J. Avian Med. Surg. 14:103-106.

Jones M.P. \& Orosz S.E. 2000. The diagnosis of aspergillosis. Sem. Avian Exot. Pet Med. 9:52-58.

Khan Z.U., Pal M., Paliwal D.K. \& Damodaram V.N. 1977. Aspergillosis in imported penguins. Sabouraudia 15:43-45.

Lane J.G. \& Warnock D.W. 1977. The diagnosis of Aspergillus fumigatus infection of the nasal chambers of the dog with particular reference to the value of the double diffusion test. J. Small Anim. Pract. 18:169177.

Maertens J., Verhaegen J., Lagrou K., Van Eldere J. \& Boogaerts M. 2001. Screening for circulating galactomannan as noninvasive diagnostic tool for invasive aspergillosis in prolonged neutropenic patients and stem cell transplantation recipients: a prospective validation. Blood 97:16041610.

Martinez-Quesada J., Nieto-Cadenazzi A. \& Torres-Rodriguez J.M. 1993 Humoral immunoresponse of pigeons to Aspergillus fumigatus antigens. Mycopathol. 124:131-137.

Nieminen S.M., Maki- Paakkanen J., Hirvonem M.R., Raponem M. \& Wright A. 2002. Genotoxicity of gliotoxin, a secondary metabolite of Aspergillus 
fumigatus, in a battery of short-term tests systems. Mutat. Res. 520:161170.

Ouchterlony 0. 1949.Antigen-antibody reactions in gels. Acta Pathol. Microbiol. Scand. 26:507-515.

Poli G., Ponti W., Balsari A., Addis F. \& Mortellaro C.M. 1981. Aspergillus fumigatus and specific precipitins in dogs with turbinate changes. Vet. Rec. 108:143-145.

Redig P.T., Orosz S. \& Cray C. 1994. The ELISA as a management guide for aspergillosis in raptors. Proc. Annual Conference of the Association of Avian Veterinarians, Reno, NV, p.99-104.

Sanchez S.L., Garret T.D. \& Sanchez C. 2005. Exhibit Modifications to reduce the incidence of aspergillosis and increase breeding in two pen- guins species at the Denver Zoo. Available at <http//www.aza.org/AZApublications/2005ProceedingsReg> Assess in November 2012.

Wheat L.J. 2003. Rapid diagnosis of invasive aspergillosis by antigen detection. Transp. Infect. Dis. 5:158-166.

Xavier M.O., Soares M.P., Cabana A.L., Silva-Filho R.P., Ruoppolo V., Meireles M.C.A. \& Severo L.C. 2011. Clinical and pathological findings of aspergillosis in Magellanic penguins (Spheniscus magellanicus). Ciênc. Anim. Bras. 12:520-524.

Xavier M.O., Soares M.P., Meinerz A.R.M., Nobre M.O., Osório L.G., SilvaFilho R.P. \& Meireles M.C.A. 2007. Aspergillosis: a limiting factor during recovery of captive Magellanic penguins. Braz. J. Microbiol. 38:480484. 